\title{
PENERAPAN ALGORITMA K-MEANS DALAM MENENTUKAN TINGKAT PENYEBARAN PANDEMI COVID-19 DI INDONESIA
}

\author{
Nayuni Dwitri, Jose A Tampubolon, Sandi Prayoga, P.P.P.A.N.W Fikrul Ilmi R.H Zer, \\ Dedy Hartama
}

\author{
Program Studi Teknik Informatika, STIKOM Tunas Bangsa Pematangsiantar \\ J1. Jend. Sudirman Blok A, No. 1,2 dan 3, Kota Pematangsiantar, Sumatera Utara \\ nayunidwitri997@gmail.com, josetampubolon28@gmail.com, sandiprayoga00@gmail.com, \\ fikrulilmizer@gmail.com, dedyhartamalamiktunasbangsa.ac.id
}

\begin{abstract}
COVID-19 is an infectious disease caused by acute coronavirus 2 (severe acute respiratory coronavirus 2 or SARS-CoV-2) respiratory syndrome. The even distribution of COVID-19 cases in all provinces in Indonesia is a fairly rapid spread and harms all fields. The vast territory of Indonesia allows the need for grouping sections by region in Indonesia. This grouping will produce center points for the spread of COVID cases - 19. K-Means is one of the Clustering algorithms that is used to divide data into several groups with a system partition. This algorithm accepts input in the form of data without class labels. Due to the global pandemic that occurred many parties sought to participate in overcoming. This research was conducted for application in the spread of the co-19 pandemic in Indonesia. In this study, the K-Means algorithm is used to determine the level of co-19 distribution in regions in Indonesia.
\end{abstract}

Keywords - Algorithms, K-Means, Covid-19, The distribution, Pandemic

\begin{abstract}
Abstrak - COVID-19 adalah penyakit yang dapat menular jika adanya kontak antara penular dengan orang lain,dan ditandai dengan gejala pada bagian pernapasan disebut SARS-CoV-2. Penyebaran kasus COVID-19 yang merata di seluruh provinsi di Indonesia,merupakan penyebaran yang cukup cepat dan berdampak negatif pada seluruh bidang. Luasnya wilayah Indonesia memungkinkan diperlukannya pengelompokkan bagian bagian berdasarkan wilayah di Indonesia.Pengelompokkan ini akan menghasilkan titik - titik pusat penyebaran kasus COVID -19. Salah satu algoritma Clustering adalah $K$-Means yang mengunakan beberapa kelompok untuk penempatan beberapa data dengan sistem partisi. Data-data tanpa label kelas diterima oleh Algoritma ini. Dikarenakan pandemi global yang terjadi banyak pihak berupaya ikut berperan serta dalam mengatasi. Penelitian ini dilakukan untuk penerapan dalam penyebaran pandemi covid-19 di Indonesia. Dalam penelitian ini mengunakan algoritma K-Means untuk menentukan bagaimana tingkat penyebaran covid-19 di daerah-daerah yang ada di Indonesia.
\end{abstract}

Kata kunci - Algoritma, K-Means , COVID-19, Penyebaran, Pandemi

\section{PENDAHULUAN}

COVID-19 adalah penyakit yang menular,dan ditandai oleh gejala pada bagian pernapasan akut (coronavirus 2 (severe acute respiratory syndrome coronavirus 2 atau SARS-CoV-2). Virus ini merupakan keluarga besar Coronavirus yang dapat menyerang hewan. Penularan virus ini terjadi jika adanya kontak antar sesama manusia.. Ketika menyerang manusia, Penyakit yang disebabkan oleh virus ini adalah penyakit infeksi saluran pernafasan, seperti flu, MERS (Middle East Respiratory Syndrome), dan SARS (Severe Acute Respiratory Syndrome).[1]

Pada tanggal 2 Maret 2020 di Indonesia sebanyak dua kasus positif COVID-19 pertama kali dilaporkan. Terkonfirmasi berjumlah 1.528 kasus dan 136 kasus kematian pada 31 Maret 2020.Tingkat kematian COVID-19 di Indonesia sebesar 8,9\%, adalah jumlah tertinggi di Asia Tenggara.[1]

Penyebaran kasus COVID-19 yang merata di seluruh provinsi di Indonesia,merupakan penyeberan yang cukup cepat dan berdampak negatif pada seluruh bidang. Luasnya wilayah Indonesia memungkinkan diperlukannya pengelompokkan bagian bagian berdasarkan wilayah di Indonesia.Pengelompokkan ini akan menghasilkan titik- titik pusat penyebaran kasus COVID-19.

K-Means merupakan salah satu algoritma Clustering yang masuk dalam kelompok Unsupervised learning yang digunakan untuk mengelompokkan data kedalam beberapa kelompok dengan sistem partisi. Algoritma ini menerima masukan berupa data tanpa label kelas. Pada algoritma K-Means, komputer menerima data-data yang tidak diketahui kelasnya terkebih dahulu lalu mengelompokkannya. Input yang diterima ialah data dan jumlah kelompok (cluster) yang diinginkan.[2] Algoritma ini akan memasukan data kedalam beberapa kelompok tersebut.

\section{METODOLOGI PENELITIAN}

\section{A. Tahap Pengumpulan Data}

Data yang digunakan untuk penelitian ini adalah data jumlah penyebaran virus COVID-19 di 
Indonesia yang diperoleh dari Kementerian Kesehatan Republik Indonesia.Data penyebaran virus COVID-19 yang digunakan pada penelitian ini adalah data penyebaran pada tanggal 9 Mei 2020.

\section{B. COVID -19}

COVID-19 adalah penyakit yang menular,dan ditandai oleh gejala pada bagian pernapasan akut (SARS-CoV-2). Virus ini merupakan keluarga besar Coronavirus yang dapat menyerang hewan. Penularan virus ini terjadi jika adanya kontak antar sesame manusia. Ketika menyerang manusia, Virus ini dapat menyebabkan penyakit infeksi saluran pernafasan, seperti MERS (Middle East Respiratory Syndrome), dan SARS (Severe Acute Respiratory Syndrome).[1] Virus ini telah tersebar lebih dari 190 negara lainnya.Oleh karena itu COVID-19 ditetapkan sebagai pandemi oleh WHO.

Sampai tanggal 8 Mei 2020, telah terjadi 3.672.238 kasus dan 245.045 kasus kematian di dunia.Sementara di Indonesia terdapat 12.776 kasus positif COVID-19 dan 930 kasus kematian. Dikarenakan pandemi global yang terjadi banyak pihak berupaya ikut berperan serta dalam mengatasi. Para dokter umum dan spesialis angkat bicara bersama guna memberi penjelasan singkat kepada masyarakat maupun imbauan agar menjaga kebersihan diri dan lingkungan sekaligus tak banyak keluar rumah.

\section{Algoritma K-Means}

Salah satu algoritma Clustering adalah $K$ Means yang digunakan untuk mengelompokkan data menjadi beberapa kelompok dengan beberapa Cluster.[2] Data - data dipilih menjadi beberapa kelompok dengan kriteria yang telah ditentukan lalu dikumpulkan menjadi satu dalam sebuah Cluster.Dimana setiap Cluster memiliki titik pusat yang disebut Centroid.

Berikut adalah tahapan-tahapan untuk melakukan optimasi mengunakan algoritma K-Means :[2]

a) Pilihlah jumlah Cluster (k) yang diinginkan pada dataset

b) Tentukan titik pusat (Centroid) secara acak/random pada tahap awal

c) Hitunglah jarak terdekat setiap data dengan Centroid.Untuk menghitung jarak terdekat dengan Centroid adalah Euclidean distance (d).Dapat mengunakan rumus di bawah ini:

$$
d e=\sqrt{(x i-s i)^{2}+(y i-t i)^{2}}
$$

Keterangan:

$(\mathrm{x}, \mathrm{y})=$ Koordinat objek

$(\mathrm{s}, \mathrm{t})=$ Koordinat Centroid

$\mathrm{i}=$ Banyaknya objek

d) Hitung kembali pusat Cluster dengan keanggotaan Cluster yang sekarang.Pusat Cluster adalah rata - rata dari semua data dalam sebuah Cluster.Dapat dihitung mengunakan rumus :

$$
V_{i j}=\frac{1}{N i} \sum_{k i}^{N i} \mathrm{Xkj}
$$

Keterangan:

$\mathrm{V}_{\mathrm{ij}}=$ Centroid rata - rata pada Cluster $\mathrm{ke}-\mathrm{i}$ untuk variabel $\mathrm{ke}-\mathrm{j}$

$\mathrm{N}_{\mathrm{i}}=$ Jumlah anggota Cluster $\mathrm{ke}-\mathrm{i}$

$\mathrm{i}, \mathrm{k}=$ Indeks dari Cluster

$\mathrm{j}=$ Indeks variabel

$\mathrm{Xkj}=$ Nilai data $\mathrm{ke}-\mathrm{k}$ variabel $\mathrm{ke}-\mathrm{j}$ untuk Cluster tersebut

e) Hitung kembali setiap objek mengunakan pusat Cluster baru (Centroid baru),ini merupakan tahap awal pembukaan iterasi baru.Jika anggota Cluster tidak mengalami perpindahan Cluster lagi,maka proses Clustering dinyatakan selesai.Tetapi,jika anggota Cluster mengalami perpindahan,maka kembali lagi pada langkah ke - c sampai anggota Cluster tidak mengalami perpindahan lagi.

\section{HASIL DAN PEMBAHASAN}

\section{A. Perhitungan dengan Algoritma K-Means}

Saat dilakukan perhitungan manual dengan data sampel sebanyak 34 provinsi yang terkena dampak penyebaran COVID-19 di Indonesia.Berikut adalah sampel data penyebaran COVID-19 di Indonesia per tanggal 9 Mei 2020:

\begin{tabular}{|c|c|c|c|}
\hline No & Provinsi & $\begin{array}{l}\text { Kasus } \\
\text { Positif }\end{array}$ & $\begin{array}{l}\text { Kasus } \\
\text { Meninggal }\end{array}$ \\
\hline 1 & Aceh & 17 & 1 \\
\hline 2 & Bali & 306 & 4 \\
\hline 3 & Banten & 523 & 56 \\
\hline 4 & Bangka Belitung & 28 & 1 \\
\hline 5 & Bengkulu & 37 & 1 \\
\hline 6 & DI Yogyakarta & 146 & 7 \\
\hline 7 & DKI Jakarta & 5056 & 427 \\
\hline 8 & Jambi & 62 & 0 \\
\hline 9 & Jawa Barat & 1437 & 95 \\
\hline 10 & Jawa Tengah & 959 & 66 \\
\hline 11 & Jawa Timur & 1419 & 141 \\
\hline 12 & Kalimantan Barat & 118 & 3 \\
\hline 13 & Kalimantan Timur & 214 & 2 \\
\hline 14 & Kalimantan Tengah & 189 & 7 \\
\hline 15 & Kalimantan Selatan & 253 & 9 \\
\hline 16 & Kalimantan Utara & 131 & 1 \\
\hline 17 & Kepulauan Riau & 101 & 10 \\
\hline 18 & Nusa Tenggara Barat & 330 & 6 \\
\hline 19 & Sumatera Selatan & 278 & 6 \\
\hline 20 & Sumatera Barat & 286 & 17 \\
\hline 21 & Sulawesi Utara & 53 & 4 \\
\hline 22 & Sumatera Utara & 179 & 21 \\
\hline 23 & Sulawesi Tenggara & 71 & 2 \\
\hline 24 & Sulawesi Selatan & 710 & 46 \\
\hline 25 & Sulawesi Tengah & 75 & 3 \\
\hline 26 & Lampung & 66 & 5 \\
\hline 27 & Riau & 71 & 6 \\
\hline 28 & Maluku Utara & 54 & 0 \\
\hline
\end{tabular}

Tabel 1. Sampel Data Penyebaran 


\begin{tabular}{|c|c|c|c|}
\hline$\overline{\text { No }}$ & Provinsi & $\begin{array}{l}\text { Kasus } \\
\text { Positif }\end{array}$ & $\begin{array}{l}\text { Kasus } \\
\text { Meninggal }\end{array}$ \\
\hline 29 & Maluku & 32 & 2 \\
\hline 30 & Papua Barat & 53 & 1 \\
\hline 31 & Papua & 277 & 6 \\
\hline 32 & Sulawesi Barat & 62 & 2 \\
\hline 33 & $\begin{array}{ll}\text { Nusa } & \text { Tenggara } \\
\text { Timur } & \end{array}$ & 12 & 0 \\
\hline 34 & Gorontalo & 19 & 1 \\
\hline
\end{tabular}

Pada tahap ini dapat diketahui bahwa :

Jumlah Cluster : 3

Jumlah Data : 34

Jumlah Atribut :2 (Kasus Positif dan Kasus Meninggal)

Iterasi ke -1

1. Menentukan centroid awal secara acak.

$\mathrm{C}_{1}$ (Jawa Timur $)=(1419,141), \mathrm{C}_{2}$ (Nusa Tenggara Barat $)=(330,6), \mathrm{C}_{3}($ Maluku $)=$ $(32,2)$

Pada Cluster penyebaran COVID-19 yang menjadi penyebaran dalam jangka besar di ambil pada data ke 11 yaitu Jawa Timur,lalu untuk Cluster dengan penyebaran jangka menengah adalah data ke 18 yaitu Nusa Tenggara Barat,dan untuk Cluster dengan penyebaran jangka kecil adalah data ke 29 yaitu Maluku.

2. Menghitung centroid terdekat. Misalnya : Aceh $(17,1)$

\begin{tabular}{c|c|c|}
\hline ACEH (C1) & $\sqrt{(17-1419)^{2}+(1-141)^{2}}$ & 1408,972675 \\
\hline \hline ACEH (C2) & $\sqrt{(17-330)^{2}+(1-6)^{2}}$ & \\
\hline \hline ACEH (C) & $\sqrt{(17-32)^{2}+(1-2)^{2}}$ & 15,0399336 \\
\hline \hline
\end{tabular}

Langkah selanjutnya ialah menghitung jarak setiap data dengan Centroid dengan persamaaan Euclidean Distance. Pada tahap ini jarak terdekat antara data dengan Cluster akan menentukan suatu data masuk ke dalam Cluster mana.Berikut adalah hasil perhitungan jarak pada Iterasi ke 1

Tabel 2.Hasil Perhitungan Iterasi 1

\begin{tabular}{|c|c|c|c|}
\hline \multirow{2}{*}{ Provinsi } & \multicolumn{3}{|c|}{ Jarak ke Centroid } \\
\cline { 2 - 4 } ACEster 1 & Cluster 2 & Cluster 3 \\
\hline BALI & 1408,972675 & 313,0399336 & 15,03329638 \\
\hline BANTEN & 1121,400018 & 24,08318916 & 274,0072992 \\
\hline BANGKA BEL. & 900,0227775 & 199,3715125 & 493,9605247 \\
\hline BENGKULU & 1398,027539 & 302,0413879 & 4,123105626 \\
\hline DIYOGYAKARTA & 1280,033072 & 293,042659 & 5,099019514 \\
\hline DKI JAKARTA & 3648,227652 & 184,0027174 & 114,1095964 \\
\hline JAMBI & 1364,305684 & 268,0671558 & 30,06659276 \\
\hline JAWA BARAT & 49,39635614 & 1110,571925 & 1408,074572 \\
\hline JAWA TENGAH & 466,0740285 & 631,8552049 & 929,2066509 \\
\hline JAWA TIMUR & 0 & 1097,335865 & 1393,947632 \\
\hline KALBAR & 1308,298513 & 212,0212254 & 86,00581376 \\
\hline KALTIM & 1212,990519 & 116,068945 & 182 \\
\hline KALTENG & 1237,277657 & 141,0035461 & 157,0795977 \\
\hline KALSEL & 1173,447911 & 77,0584194 & 221,1108319 \\
\hline KALUT & 1295,586354 & 199,0628042 & 99,00505038 \\
\hline KEP.RIAU & 1324,494243 & 229,0349318 & 69,46221995 \\
\hline NTB & 1097,335865 & 0 & 298,0268444 \\
\hline SUMSEL & 1148,958659 & 52 & 246,0325182 \\
\hline SUMBAR & 1139,765327 & 45,35416188 & 254,4425279 \\
\hline SULUT & 1372,852869 & 277,0072201 & 21,09502311 \\
\hline SUMUT & 1245,79292 & 151,7432041 & 148,2228053 \\
\hline SULTRA & 1355,147593 & 259,0308862 & 39 \\
\hline \multicolumn{4}{|c|}{} \\
\hline
\end{tabular}

\begin{tabular}{|c|c|c|c|}
\hline \multirow{2}{*}{ Provinsi } & \multicolumn{3}{|c|}{ Jarak ke Centroid } \\
\cline { 2 - 4 } & Cluster 1 & Cluster 2 & Cluster 3 \\
\hline SULSEL & 715,3362846 & 382,0994635 & 679,4262285 \\
\hline SULTENG & 1351,066246 & 255,0176464 & 43,01162634 \\
\hline LAMPUNG & 1359,818003 & 264,0018939 & 34,13209633 \\
\hline RIAU & 1354,743149 & 259 & 39,20459157 \\
\hline MALUKU UTARA & 1372,263094 & 276,0652097 & 22,09072203 \\
\hline MALUKU & 1393,947632 & 298,0268444 & 0 \\
\hline PAPUA BARAT & 1373,15549 & 277,0451227 & 21,02379604 \\
\hline PAPUA & 1149,951738 & 53 & 245,0326509 \\
\hline SULBAR & 1364,100436 & 268,0298491 & 30 \\
\hline NTT & 1414,047383 & 318,0565987 & 20,09975124 \\
\hline GORONTALO & 1406,982587 & 311,0401903 & 13,03840481 \\
\hline
\end{tabular}

3. Melakukan pengelompokkan berdasarkan cluster.Berikut adalah hasil pemgelompokkan cluster pada Iterasi 1:

Tabel 3. Pengelompokkan Cluster Iterasi 1

\begin{tabular}{|c|c|}
\hline Provinsi & Jarak Terdekat \\
\hline ACEH & C3 \\
\hline BALI & $\mathrm{C} 2$ \\
\hline BANTEN & $\mathrm{C} 2$ \\
\hline BANGKA BEL. & $\mathrm{C} 3$ \\
\hline BENGKULU & C3 \\
\hline DIYOGYAKARTA & $\mathrm{C} 3$ \\
\hline DKI JAKARTA & $\mathrm{C} 1$ \\
\hline JAMBI & C3 \\
\hline JAWA BARAT & $\mathrm{C} 1$ \\
\hline JAWA TENGAH & $\mathrm{C} 1$ \\
\hline JAWA TIMUR & $\mathrm{C} 1$ \\
\hline KALBAR & C3 \\
\hline KALTIM & $\mathrm{C} 2$ \\
\hline KALTENG & $\mathrm{C} 2$ \\
\hline KALSEL & $\mathrm{C} 2$ \\
\hline KALUT & $\mathrm{C} 3$ \\
\hline KEP.RIAU & $\mathrm{C} 3$ \\
\hline NTB & $\mathrm{C} 2$ \\
\hline SUMSEL & $\mathrm{C} 2$ \\
\hline SUMBAR & $\mathrm{C} 2$ \\
\hline SULUT & $\mathrm{C} 3$ \\
\hline SUMUT & $\mathrm{C} 3$ \\
\hline SULTRA & $\mathrm{C} 3$ \\
\hline SULSEL & $\mathrm{C} 2$ \\
\hline SULTENG & $\mathrm{C} 3$ \\
\hline LAMPUNG & $\mathrm{C} 3$ \\
\hline RIAU & C3 \\
\hline MALUKU UTARA & $\mathrm{C} 3$ \\
\hline MALUKU & C3 \\
\hline PAPUA BARAT & $\mathrm{C} 3$ \\
\hline PAPUA & $\mathrm{C} 2$ \\
\hline SULBAR & C3 \\
\hline NTT & $\mathrm{C} 3$ \\
\hline GORONTALO & $\mathrm{C} 3$ \\
\hline
\end{tabular}

4. Menentukan Centroid baru untuk iterasi berikutnya dengan mencari rata-rata nilai dari setiap cluster.Berikut adalah nilai centroid baru untuk iterasi 2

\begin{tabular}{|l|l|r|r|}
\hline \multirow{3}{*}{ Centroid } & C1 & 2217,8 & 182,25 \\
\cline { 2 - 4 } & C2 & 336,6 & 15,9 \\
\cline { 2 - 4 } & C3 & 69,35 & 3,55 \\
\hline
\end{tabular}


Jika tahapan iterasi telah mencapai hasil yang sama tanpa ada perpindahan lagi, maka perhitungan dihentikan.

Pada penelitian ini iterasi dilakukan sampai iterasi ke 6. Hasil akhir posisi Cluster dari Centroid iterasi ke 6 dapat dilihat pada table dibawah ini:

Tabel 4.Pembagian Cluster pada Iterasi ke -6

\begin{tabular}{|l|l|}
\hline Provinsi & Letak Cluster \\
\hline Aceh & C3 \\
\hline Papua Barat & C3 \\
\hline Banten & C3 \\
\hline Bangka Bel. & C3 \\
\hline Yogyakarta & C3 \\
\hline DKI Jakarta & C1 \\
\hline Maluku Utara & C3 \\
\hline Jawa Barat & C2 \\
\hline Jawa Tengah & C2 \\
\hline Jawa Timur & C2 \\
\hline Kalbar & C3 \\
\hline Kaltim & C3 \\
\hline Kalteng & C3 \\
\hline Kalsel & C3 \\
\hline Kalut & C3 \\
\hline Kep.Riau & C3 \\
\hline Bali & C3 \\
\hline Sumbar & C3 \\
\hline Sulut & C3 \\
\hline Sumut & C3 \\
\hline Sultra & C3 \\
\hline Sulsel & C2 \\
\hline Sulteng & C3 \\
\hline Lampung & C3 \\
\hline NTB & C3 \\
\hline Maluku & C3 \\
\hline Sumsel & C3 \\
\hline Papua & C3 \\
\hline Sulbar & C3 \\
\hline NTT & C3 \\
\hline Gorontalo & C3 \\
\hline Jambi & C3 \\
\hline Riau & C3 \\
\hline & \\
\hline
\end{tabular}

Hasil Pengolahan Data secara manual dengan 34 Provinsi dapat dilihat pada gambar berikut ini:

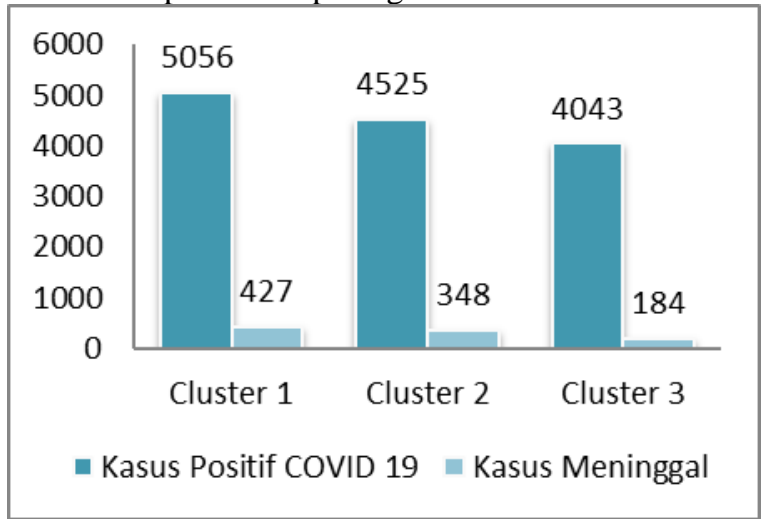

Gambar 1. Cluster tingkat penyebaran COVID-19
Hasil yang didapat dari grafik tesebut adalah Cluster 1 sebagai penyebaran dalam jangka besar yaitu sebanyak 5056 kasus pasien positif COVID-19 dengan 427 kasus meninggal.Untuk Cluster 2 sebagai penyebaran dalam jangka menengah yaitu dengan 4525 kasus positif COVID-19 dengan 348 kasus meninggal.Dan pada Cluster 3 sebagai penyebaran jangka kecil yaitu dengan 4043 kasus positif COVID19 dengan 184 kasus meninggal.

\section{B. Implementasi Pada Aplikasi RapidMiner}

Dalam pengimplementasian pada aplikasi RapidMiner dapat dilihat sebagai berikut:

1. Import Data kedalam RapidMiner dalam bentuk sheet Excel

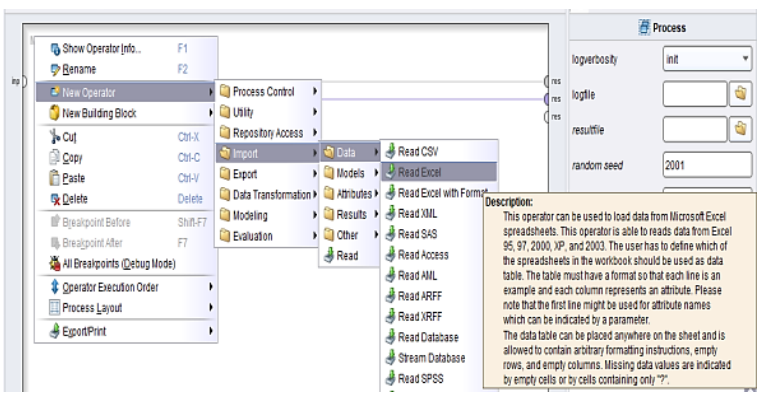

Gambar 2. Import Data

2. Import Configuration Wizard

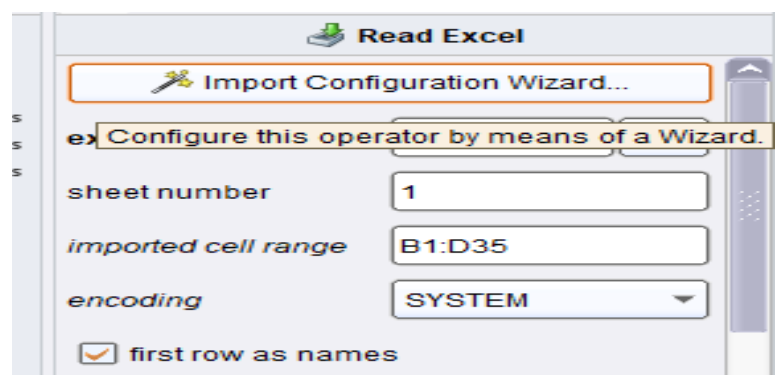

Gambar 3. Konfigurasi Wizard

3. Pilih File, sesuaikan Anotasi dan Memilih Atribut dan Tipe Data

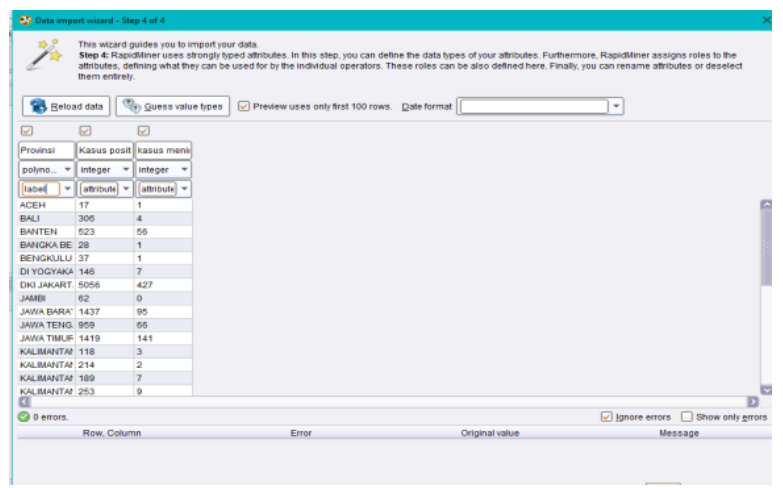

Gambar 4. Penyesuaian Atribut dan TipeData 
4. Menambahkan Model K-Means

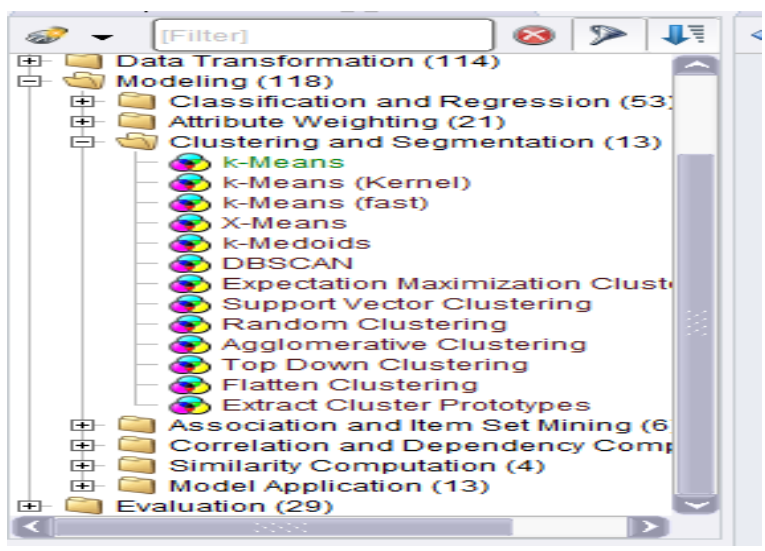

Gambar 5. Pemilihan Model K-Means

5. Menghubungkan Model K-Means

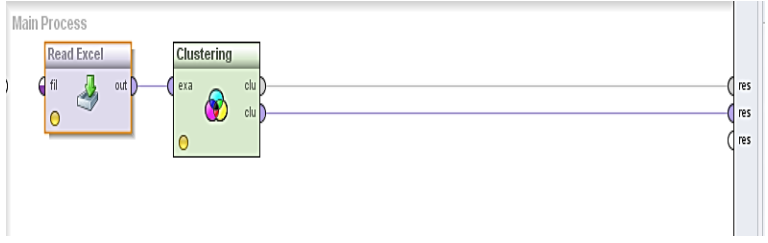

Gambar 6. Menghubungkan K-Means

6. Jalankan Project

Tampilan Text View

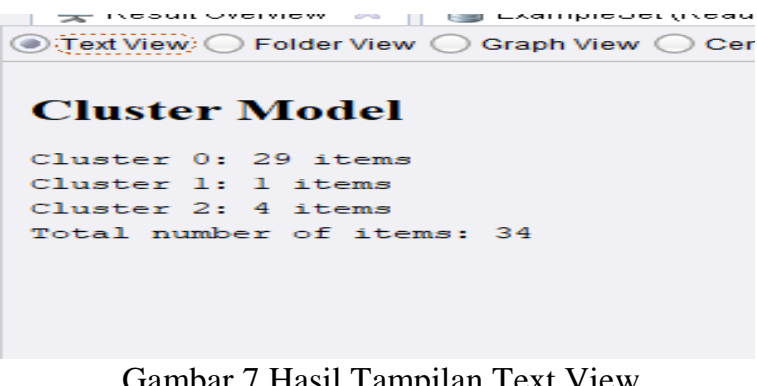

Tampilan Plot View

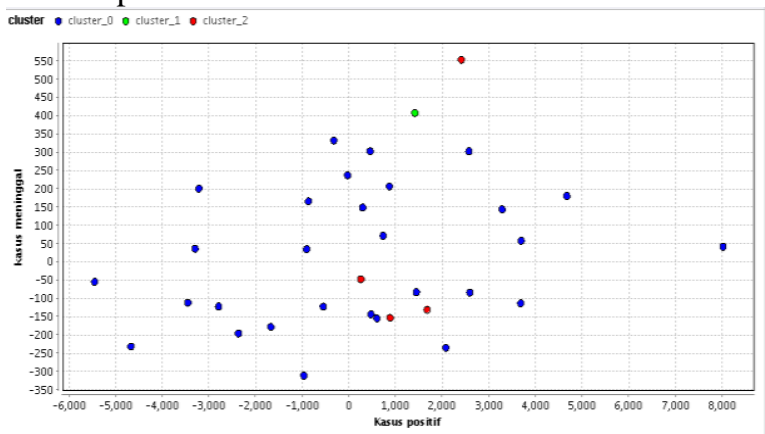

Gambar 8.Hasil Tampilan Plot View

Setelah melakukan implementasi mengunakan Aplikasi RapidMiner ,hasil yang didapat setelah di implementasikan pada RapidMiner samadengan hasil pada perhitungan manual.

\section{KESIMPULAN}

Berdasarkan penelitian dan hasil perhitungan mengunakan Algoritma K-Means dalam penyebaran COVID-19 di Indonesia,maka dapat ditarik kesimpulan sebagai berikut :

1. Pusat Cluster yang diperoleh yaitu untuk Cluster pertama berada pada provinsi DKI Jakarta.Pusat Cluster kedua berada pada provinsi Jawa Barat,dan pusat Cluster ketiga berada pada provinsi Banten

2. Pusat Cluster pertama merupakan daerah penyebaran COVID-19 terbesar di Indonesia dengan kasus positif dan kasus meninggal paling besar.

3. Daerah -daerah pada Cluster kedua dan ketiga merupakan penyebaran kasus COVID-19 yang cukup potensial,sehingga harus ,menjadi perhatian pemerintah untuk penanganannya

\section{DAFTAR PUSTAKA}

[1] A.R. Setiawan, Lembar Kegiatan Literasi Saintifik untuk Pembelajaran Jarak Jauh Topik Penyakit Coronavirus 2019 (COVID-19), Edukatif: Jurnal Ilmu Pendidikan Vol 2, No 1, 2020.

[2] A. Wanto, et al, Data Mining : Algoritma dan Implementasi, Medan : Yayasan Kita Menulis, 2020 .

[3] T. Naibaho, et al . Kemampuan Siswa Menentukan Turunan Fungsi Aljabar Dengan Pembelajaran Model Kooperatif Tipe NHT (Kasus: Di Kelas XI MIA SMA Swasta Cerdas Bangsa Namurambe Tahun Pelajaran 2017/2018), Seminar Nasional Matematika dan Terapan, Vol. 1, 2019.

[4] M.T.I. Rahmayani, Analisis Clustering Tingkat Keparahan Penyakit Pasien Menggunakan Algoritma K-Means (Studi Kasus di Puskesmas Bandar Seikijang), JITI, Vol.1, No. 2, 2018.

[5] A. Susilo, et al, Coronavirus Disease 2019: Tinjauan Literatur Terkini . Jurnal Penyakit Dalam Indonesia, Vol. 7, No. 1, 2020.

[6] N. Meisida, et al. K-Means untuk KLASIFIKASI PENYAKIT KARIES GIGI, Kumpulan jurnal Ilmu Komputer (KLIK) Volume 01, No.01, 2014

[7] A. Bastian, et al, PENERAPAN ALGORITMA $K$ MEANS CLUSTERING ANALYSIS PADA PENYAKIT MENULAR MANUSIA (STUDI KASUS KABUPATEN MAJALENGKA). Jurnal Sistem Informasi (Journal of Information System), Volume 14, Issue 1, 2018.

[8] F. Nasari, et al. Penerapan Algoritma K-Means Clustering Untuk Pengelompokkan Penyebaran Diare Di Kabupaten Langkat. Cogito Smart Journal, VOL. 2, NO. 2, 2016. 